\title{
Perlindungan Hukum Terhadap Pengguna Aplikasi E-Commerce yang Terdampak Kebocoran Data Pribadi
}

\author{
Maldi Omar Muhammad ${ }^{1}$, Lucky Dafira Nugroho ${ }^{* *}$ \\ Fakultas Hukum Universitas Trunojoyo Madura \\ Jl. Raya Telang 02 Kamal Bangkalan Madura 69162 Jawa Timur
}

*Email : lucky.dafira@trunojoyo.ac.id

Naskah diterima 13 September 2021, Revisi 2 Oktober 2021, Terbit 29 Oktober 2021

DOI: doi.org/10.21107/pamator.v14i2.12472

\begin{abstract}
Technological developments continue to develop very rapidly, one of which is in the electronic trading system, hereinafter referred to as e-commerce. Along with this, there are concerns from E-Commerce application media users regarding personal data stored by E-Commerce application media companies, so that more specific rules are needed regarding legal protection for E-Commerce application users. The purpose of this research is to further review the rules related to legal protection for users who are affected by the leakage of personal data on E-Commerce media such as based on the agreement in the Terms and Conditions as well as the rules of related laws such as, the ITE Law and its amendments, PP 71/2019 concerning the Implementation of Electronic Systems and Transactions, Government Regulation Number 80 of 2019 concerning Trading Through Electronic Systems, Regulation of the Minister of Communication and Information Technology Number 20 of 2016 concerning Protection of Personal Data in Electronic Systems. The method used in this research is normative juridical research, with a statutory approach. The collection of sources of legal materials, both primary and secondary, is carried out through laws and regulations and all official documents that contain legal provisions and searches related to research results such as journals and the internet.
\end{abstract}

Keywords: E-Commerce, electronic, personal data

\section{PENDAHULUAN}

Teknologi informasi merupakan salah satu bentuk perkembangan zaman yang memiliki dampak pada kesejahteraan masyarakat terutama dalam bidang ekonomi. Internet saat ini tidak hanya digunakan sebagai sarana komunikasi dan informasi, tetapi dalam berbagai situasi dapat dijadikan sebagai sumber pendapatan bagi seseorang dalam perekonomian. Internet selain menjadi sumber pendapatan juga bisa menjadi cara untuk memenuhi keinginan orang yang ingin berbelanja dengan cepat dan praktis tanpa harus mengecek kapan, dimana dan dalam keadaan apa, dan semua ini bisa dibuat lebih mudah dengan belanja online. Belanja online sangat diminati untuk memenuhi kebutuhan atau keinginannya karena sebagai pengguna mereka dapat berbelanja tanpa harus bertemu langsung dengan penjual.

Pertumbuhan belanja online membuktikan bahwa teknologi memberikan dampak positif terutama dalam bidang ekonomi dan bisnis.
Teknologi tidak hanya membawa manfaat, tetapi teknologi juga membawa risiko keamanan. Banyak partai politik yang tidak bertanggung jawab menyalahgunakan teknologi internet untuk melakukan kejahatan. Dapat dikatakan orang Indonesia itu cepat melupakan sesuatu.

Kepercayaan publik terhadap Tokopedia akan pulih dengan cepat. Bisnis akan berjalan kembali normal saat orang-orang membutuhkan Tokopedia untuk belanja online. Pemanfaatan internet dalam berbagai bidang kehidupan tidak saja membuat segala sesuatunya menjadi lebih mudah, tetapi juga melahirkan permasalahan termasuk masalah hukum. Salah satu masalah hukum yang muncul adalah masalah yang berkaitan dengan perlindungan data pribadi (the protection of privacy rights). Terkait privasi dalam transaksi online, pengguna diharuskan untuk mengungkapkan sejumlah besar informasi pribadi kepada penjual. Hal tersebut rentan dengan kebocoran informasi 
sensitif sehingga memicu terjadinya pelanggaran data dan pencurian identitas seperti pembobolan rekening atau pemerasan. Akibat yang ditimbulkan dari tindakan pencurian data yang dilakukan oleh pihak ketiga atau disebut hacker biasanya yang menjadi sasaran dari hasil pencurian data ialah :

a. Database kartu kredit

b. Database account bank

c. Database informasi pelanggan atau data pribadi

d. Serta melakukan Tindakan kriminal dengan menggunakan database kartu kredit orang lain yang bukan hak kita (carding)

e. Mengacaukan system

Dalam hal ini produsen (penjual barang/jasa) dan pengguna pengguna aplikasi media e-commerce juga memiliki resiko yang lebih besar daripada penyedia aplikator, dengan kata lain hak-hak pengguna sangat rentan dan mudah untuk dilanggar. Pengguna memiliki sejumlah hak hukum yang perlu untuk mendapatkan perlindungan dalam pemenuhannya. hak-hak itu perlu mendapatkan pemahaman dan penghargaan dari semua pihak, dalam kehidupan berbangsa dan bernegara (Sidabalok, 2014). Oleh karena itu pengguna mempunyai hak yang diatur dalam Pasal 26 Undang-Undang Nomor 11 Tahun 2008 tentang Informasi dan Transaksi Elektronik mensyaratkan bahwa penggunaan setiap data pribadi dalam sebuah media elektronik harus mendapat persetujuan pemilik data bersangkutan. Setiap orang yang melanggar ketentuan ini dapat digugat atas kerugian yang ditimbulkan. Bunyi Pasal 26 UU ITE adalah sebagai berikut :

(1) Penggunaan setiap informasi melalui media elektronik yang menyangkut data pribadi seseorang harus dilakukan atas persetujuan orang yang bersangkutan.

(2) Setiap orang yang dilanggar haknya sebagaimana dimaksud pada ayat (1) dapat mengajukan gugatan atas kerugian yang ditimbulkan berdasarkan Undang-Undang ini.

Serta penyedia aplikasi dengan para pengguna aplikasi tersebut secara tidak langsung juga mengandung Asas konsensualisme yang dapat disimpulkan dalam Pasal 1320 ayat (1) BW. Pada pasal tersebut ditentukan bahwa salah satu syarat sahnya perjanjian adalah adanya kata kesepakatan antara kedua belah pihak. Karena sebelum pengguna membuat akun untuk akses login ke web atau aplikasi tersebut terdapat sebuah syarat dan ketentuan antara pengguna dengan penyedia aplikasi. Maka dari situlah timbulah adanya suatu perjanjian kedua belah pihak. Dalam hal tersebut pelaku usaha selaku sebagai pihak yang menyelenggarakan jasa layanan media e-commerce seharusnya mempunyai peran dalam melindungi hak dari para pengguna nya. Hak pengguna merupakan sebuah tanggung jawab pelaku usaha agar usaha jasa tersebut bisa menjadi berjalan dengan lancar, sehingga pengguna merasa aman dan nyaman dalam menggunakan aplikasi tersebut, serta memberikan Tindakan lebih lanjut agar permasalahan yang terjadi tidak menjadi berlanjut karena dapat merugikan kedua belah pihak yaitu produsen (penjual barang/jasa) dan pengguna pengguna media belanja online atau e-commerce.

\section{METODOLOGI}

Jenis penelitian yang digunakan dalam penelitian ini menggunakan metode penelitian normatif. Metode penelitian normatif adalah metode atau cara yang dipergunakan di dalam penelitian hukum yang dilakukan dengan cara meneliti bahan pustaka yang ada. (Soekanto dan Mamudji, 2009). Pokok kajiannya adalah hukum yang dikonsepkan sebagai norma atau kaidah yang berlaku dalam masyarakat dan menjadi acuan perilaku setiap orang, sehingga penelitian hukum normatif berfokus pada inventarisasi hukum positif, asas-asas dan doktrin hukum, penemuan hukum dalam perkara in concreto, sistematik hukum, taraf sinkronisasi hukum, dan perbandingan hukum (Muhammad, 2004).

Metode pendekatan yang digunakan adalah Statute Approach (Pendekatan Undang-Undang), dilakukan dengan menelaah semua Undang-Undang dan regulasi yang bersangkut paut dengan isu hukum yang sedang ditangani. Dalam melaksanakan penelitian normatif-empiris membutuhkan sumber bahan hukum yaitu sumber hukum primer, sekunder dan tersier.

Bahan hukum primer merupakan bahan hukum yang utama, sebagai bahan hukum yang bersifat autoritatif, yakni bahan hukum 
yang mempunyai otoritas, Bahan hukum primer meliputi peraturan perundangundangan dan segala dokumen resmi yang memuat ketentuan hukum. Bahan hukum sekunder merupakan bahan hukum tambahan untuk pendukung dan penguatan sumber bahan hukum primer meliputi buku hukum, artikel dan makalah. Bahan hukum tersier merupakan bahan hukum pelengkap dari bahan hukum primer dan sekunder. Bahan hukum tersier ini memberikan petunjuk dan penjelasan mengenai bahan hukum primer dan sekunder.

\section{HASIL DAN PEMBAHASAN}

Kemajuan teknologi informasi telah melahirkan inovasi baru di sektor jasa keuangan. Berbagai perubahan dalam sistem transaksi terjadi di dalam kehidupan manusia. Manusia yang dulunya bertransaksi secara langsung atau bertatap muka saat ini bisa melakukan transaksi melalui teknologi informasi. Perkembangan teknologi informasi bisa memunculkan permasalahan hukum yang berdampak bagi masyarakat sehingga harus dihadapi oleh hukum sebagaimana mestinya (Barkatullah, 2006).

\section{Perlindungan Hukum Pengguna Aplikasi E-commerce Yang Mengalami Kegagalan Perlindungan Data Pribadi}

Isnaeni (2016) berpendapat pada dasarnya persoalan "perlindungan hukum itu ditinjau dari sumbernya dapat dibedakan menjadi dua macam yakni perlindungan hukum "eksternal" dan perlindungan hukum "internal." Hakekat perlindungan hukum internal, pada dasarnya perlindungan hukum yang dimaksud dikemas sendiri oleh para pihak pada saat membuat perjanjian, di mana pada waktu mengemas klausula-klausula kontrak, kedua belah pihak menginginkan agar kepentingannya terakomodir atas dasar kata sepakat. Demikian juga segala jenis resiko diusahakan dapat ditangkal lewat pemberkasan lewat klausula-klausula yang dikemas atas dasar sepakat pula, sehingga dengan klausula itu para pihak akan memperoleh perlindungan hukum berimbang atas persetujuan mereka bersama. Perihal perlindungan hukum internal seperti itu baru dapat diwujudkan oleh para pihak, manakala kedudukan hukum mereka relatif sederajad dalam arti para pihak mempunyai bargaining power yang relatif berimbang, sehingga atas dasar asas kebebasan berkontrak masingmasing para pihak yang terlibat perjanjian itu mempunyai keleluasaan untuk menyatakan kehendak sesuai kepentingannya. "Pola ini dijadikan landasan pada waktu para pihak merakit klausula-klausula perjanjian yang sedang digarapnya, sehingga perlindungan hukum dari masing-masing pihak dapat terwujud secara lugas atas inisiatif mereka."

Bahwa sering terjadi para pengguna aplikasi online tidak membaca disclaimer (pertanyaan yang menyangkal) ataupun membaca terms of use (syarat penggunaan) dengan berbagai alasan. Dalam situasi keadaan yang seperti itu dapat dipastikan pengguna memiliki beberapa opsi pilihan yakni : take it or leave it; yes or no; agree or disagree dan jika pengguna aplikasi ingin melanjutkan maka pilihannya ialah yes, agree, take it. Setelah data pribadi yang kita unggah ke dalam sistem elektronik menjadi informasi elektronik dalam sistem penyelenggara/platform atau penyedia jasa layanan yang wajib dijaga apabila pengguna meng-klik dengan menekan tombol yes/ agree/ okay, maka hal tersebut adalah bentuk pernyataan kesepakatan atau/ otentikasi antara pengguna dengan aplikasi e-commerce tersebut.

Dalam hal ini, perlu diketahui bahwasannya Tokopedia dapat mengakses data pribadi para pengguna untuk beberapa kepentingan seperti menyajikan layanan yang tersedia pada situs serta dapat memproses segala bentuk aktivitas Pengguna dalam Situs termasuk memproses transaksi, verifikasi pembayaran, promosi, dan pengiriman produk; menyelenggarakan promosi perlombaan, atau layanan khusus yang tersedia pada situs, seperti program tukar tambah atau langsung laku yang diselenggarakan Tokopedia; kepentingan penyelesaian transaksi antara Pembeli dan Penjual pada Situs; kegiatan pemasaran yang dilakukan oleh vendor, konsultan, mitra pemasaran, firma/ lembaga riset, atau penyedia layanan sejenis.

Hal ini disebutkan juga bahwasannya Pihak Tokopedia tidak memberikan kompensasi apabila terjadi kegagalan perlindungan data pribadi. Walaupun dalam Terms of use Tokopedia dijelaskan juga bahwa pihak berusaha melindungi setiap data pribadi pengguna yang disimpan dalam sistemnya, serta melindungi data tersebut 
dari akses, penggunaan, modifikasi, pengambilan dan/atau pengungkapan tidak sah dengan menggunakan sejumlah tindakan dan prosedur keamanan, termasuk kata sandi dan kode OTP (One Time Password) Pengguna. Pihak Tokopedia juga mengungkapkan data pribadi pengguna dalam upaya mematuhi kewajiban hukum dan/atau adanya suatu permintaan yang sah dari aparat penegak hukum atau instansi penyelenggara negara yang berwenang. Namun, perlu diketahui bahwasannya pengiriman data melalui internet tidak pernah sepenuhnya aman. Dengan demikian, pihak Tokopedia tidak dapat menjamin 100\% keamanan data yang disediakan atau dikirimkan kepada pihak Tokopedia oleh pengguna dan pemberian informasi oleh pengguna merupakan risiko yang ditanggung oleh pengguna sendiri.

Sedangkan dalam perlindungan hukum eksternal ini, pada umumnya merupakan sebuah benteng yang dipersiapkan oleh pembentuk undang-undang demi menangkal kerugian juga ketidakadilan, bagi para pelaku pasar yang secara potensial dapat menimpa salah satu kontrakan. Pentingnya ketersediaan perlindungan hukum eksternal ini, merupakan usaha dari penguasa agar tatanan bisnis tetap bergerak dalam koridor yang patut dan adil. Pada umumnya, perlindungan hukum eksternal dipersiapkan oleh pembentuk undang-undang, untuk mengantisipasi adanya eksploitasi yang dilakukan oleh salah satu kontraktan yang pada dasarnya punya bargaining position yang lebih unggul dari rekannya. Dirasa perlu oleh pemerintah, agar pihak yang lemah tetap dapat memperoleh keuntungan secara wajar, selama menggunakan kontrak sebagai wahana komersial yang dikemudikannya. Sebaliknya perlindungan hukum eksternal ini, sekaligus merupakan pembatas-pembatas yang sengaja dibuat oleh penguasa, supaya pihak yang kuat tidak akan menggunakan asas kebebasan berkontrak secara tidak patut, demi meraih keuntungan atas kerugian mitranya (Isnaeni, 2017).

Landasan yuridis tentang perlindungan data pribadi, bersumber kepada pasal 28G UUD 1945. Dengan demikian perlindungan data pribadi merupakan salah satu bentuk perwujudan amanat konstitusi dan harus diatur dalam bentuk undang-undang. Pasal 28G UUD 1945 Amandemen Keempat menyatakan bahwa "Setiap orang berhak atas perlindungan diri pribadi, keluarga, kehormatan, martabat dan harta benda yang dibawah kekuasaan nya, serta berhak atas rasa aman dan perlindungan dari ancaman ketakutan untuk berbuat atau tidak berbuat sesuatu merupakan hak asasi".

Adapun peraturan perundang - undangan di Indonesia yang berkatian dengan perlindungan masyarakat atas data pribadi miliknya antara lain (1) UU ITE beserta perubahannya, (2) PP 71/2019 tentang Penyelenggaraan Sistem Dan Transaksi Elektronik, (3) Peraturan Pemerintah Nomor 80 Tahun 2019 tentang Perdagangan Melalui Sistem Elektronik (4) Peraturan Menteri Komunikasi Dan Informatika Nomor 20 Tahun 2016 Tentang Perlindungan Data Pribadi Dalam Sistem Elektronik. Dari keempat ketentuan peraturan perundang undangan tersebut sampai saat ini belum ada regulasi yang secara khusus mengatur mengenai perlindungan data pribadi masyarakat terkait dengan penggunaanya dalam sistem elektronik. Perlindungan data pribadi masih menjadi bagian dari regulasi terkait dengan penyelenggaraan informasi dan transaksi elektronik karena isu perlindungan data pribadi ini mencuat saat banyaknya data pribadi masyarakat yang disimpan dalam sistem elektronik. Dalam pemanfaatan teknologi Informasi, perlindungan data pribadi merupakan salah satu bagian dari hak privasi. Untuk memberikan rasa aman bagi pengguna sistem elektronik, UU ITE diatur mengenai perlindungan atas data pribadi dan hak privasi yang tertuang dalam Pasal 25 dan 26 ayat (1) UU ITE yaitu :

\section{Pasal 25}

Informasi Elektronik dan/atau Dokumen Elektronik yang disusun menjadi karya intelektual, situs internet, dan karya intelektual yang ada di dalamnya dilindungi sebagai Hak Kekayaan intelektual berdasarkan ketentuan Peraturan Perundang-undangan.

\section{Pasal 26}

(1) Kecuali ditentukan lain oleh peraturan perundang-undangan, penggunaan setiap informasi melalui media elektronik yang menyangkut data pribadi seseorang yang harus dilakukan atas persetujuan orang yang bersangkutan. 
(2) Setiap orang yang dilanggar haknya sebagaimana dimaksud pada ayat (1) dapat mengajukan gugatan atas kerugian yang ditimbulkan berdasarkan Undang-Undang ini.

\section{Pasal 15}

(1) Setiap Penyelenggara Sistem Elektronik harus menyelenggarakan Sistem Elektronik secara andal dan aman serta bertanggung jawab terhadap beroperasinya Sistem Elektronik sebagaimana mestinya.

(2) Penyelenggara Sistem Elektronik bertanggung jawab terhadap Penyelenggaraan Sistem Elektroniknya.

(3) Ketentuan sebagaimana dimaksud pada ayat (2) tidak berlaku dalam hal dapat dibuktikan terjadinya keadaan memaksa, kesalahan, dan/atau kelalaian pihak pengguna Sistem Elektronik

Penjelasan Pasal 26 ayat (1) UU ITE menyebutkan bahwa hak pribadi dalam pasal tersebut mengandung beberapa pengertian yaitu (1) hak merupakan hak untuk menikmati kehidupan pribadi dan bebas dari segala macam gangguan, (2) hak pribadi merupakan hak untuk dapat berkomunikasi dengan orang lain tanpa tindakan mematamatai, dan (3) Hak pribadi merupakan hak untuk mengawasi akses informasi tentang kehidupan pribadi dan data seseorang. Dengan demikian, sebagaimana ditentukan dari Pasal 26 ayat (1) - (2) UU ITE, penggunaan setiap informasi dan data pribadi melalui media elektronik yang dilakukan tanpa persetujuan pemilik data tersebut adalah sebuah pelanggaran. Meskipun terdapat pengakuan atas perlindungan hak privasi atas data pribadi dalam informasi dan transaksi elektronik dalam Pasal 26 ayat (1) - (2) UU ITE. Pasal 26 ayat (1) UU ITE jelas kepada penyelenggara sistem elektronik untuk memberikan upaya perlindungan data pribadi.

Dalam penggunaan setiap informasi yang berkaitan dengan data pribadi seseorang harus dilakukan oleh orang yang bersangkutan yaitu pemilik data pribadi. Mengenai siapa yang harus menjaga perlindungan data pribadi ialah terdapat pada Pasal 15 ayat (1) UU ITE yang berbunyi "Setiap Penyelenggara Sistem Elektronik harus menyelenggarakan Sistem Elektronik secara andal dan aman serta bertanggung jawab terhadap beroperasinya Sistem Elektronik sebagaimana mestinya". Oleh karena itu, data pribadi wajib di jaga secara andal dan aman agar tidak terjadinya suatu kegagalan perlindungan data pribadi pada media e-commerce.

Definisi dari data pribadi tidak ditemukan dalam UU ITE, tetapi dijelaskan dalam Pasal 1 angka 29 Peraturan Pemerintah Nomor 71 tahun 2019 Tentang Penyelenggaraan Sistem dan Transaksi Elektronik, yang selanjutnya disebut PP PSTE. Dalam Pasal 1 angka 29 PP PSTE disebutkan bahwa yang dimaksud dengan data pribadi adalah "setiap data tentang seseorang baik yang teridentifikasi dan/atau dapat diidentifikasi secara tersendiri atau dikombinasi dengan informasi lainnya baik secara langsung maupun tidak langsung melalui Sistem Elektronik dan /atau non-elektronik". Tokopedia yang menjadi fokus penelitian ini merupakan penyelenggaraan sistem elektronik lingkup privat. Berdasarkan Pasal 3 ayat (1) diamanatkan bahwa penyelenggara sistem elektronik harus menyelenggarakan sistem elektronik yang handal dan aman dalam beroperasinya sistem elektronik. Hal ini juga ditegaskan dalam ketentuan Pasal 31 PP PSTE dimana penyelenggara Sistem Elektronik wajib melindungi penggunanya dan masyarakat luas dari kerugian yang ditimbulkan oleh Sistem Elektronik yang diselenggarakannya.

Perlindungan data pribadi juga diatur dalam Peraturan Pemerintah Nomor 80 Tahun 2019 tentang Perdagangan Melalui Sistem Elektronik, yang selanjutnya disebut PP PMSE. Dalam PP PMSE juga mengatur mengenai perlindungan terhadap data pribadi dalam konteks perdagangan melalui sistem elektronik yang tertuang dalam Pasal 58 - Pasal 59 PP PMSE. Berdasarkan Pasal 58 ayat (1) PP PMSE bahwa "setiap data pribadi diberlakukan sebagai hak milik pribadi dari orang atau Pelaku Usaha yang bersangkutan" dan Pasal 58 ayat (2) PP PMSE bahwa "Setiap Pelaku Usaha yang memperoleh data pribadi sebagaimana dimaksud pada ayat (1) wajib bertindak sebagai pengemban amanat dalam menyimpan dan menguasai data pribadi sesuai dengan ketentuan peraturan perundang-undangan". Dalam ketentuan Pasal 58 - 59 PP PMSE hanya mengatur amanah kepada pelaku usaha untuk 
mengelola data pribadi milik masyarakat tanpa adanya regulasi terkait sanksi atau tanggung jawab bilamana terjadi kegagalan dalam perlindungan data pribadi.

Selain itu, perlindungan data pribadi juga di atur dalam Peraturan Menteri Komunikasi dan Informatika Nomor 20 Tahun 2016 Tentang Perlindungan Data Pribadi Dalam Sistem Elektronik, yang selanjutnya disebut PERMENKOMINFO 20/2016. Data pribadi yang dimaksudkan adalah data yang dimiliki oleh perseorangan atau pribadi tertentu yang wajib disimpan, dirawat, dan dijaga kebenaran serta dilindungi kerahasiaannya (vide Pasal 1 angka 1 PERMENKOMINFO 20/2016). Ruang lingkup perlindungan data pribadi meliputi "perolehan data, pengumpulan data, pengolahan data, penganalisisan data, penyimpanan data, penampilan, pengumuman, pengiriman, penyebarluasan, dan pemusnahan data pribadi" (vide Pasal 2 PERMENKOMINFO 20/2016). Dalam pelaksanaan perlindungan data pribadi harus didasarkan pada asas asas yang sebagaimana diatur dalam Pasal 2 ayat (2) PERMENKOMINFO 20/2016 yang antara lain :

a. Penghormatan terhadap data pribadi sebagai privasi;

b. Data pribadi bersifat rahasia sesuai persetujuan dan/atau berdasarkan ketentuan peraturan perundangundangan;

c. Berdasarkan persetujuan;

d. Relevansi dengan tujuan perolehan, pengumpulan, penganalisisan, pengolahan, penampilan, pengumuman, pengiriman, dan penyebarluasan;

e. Kelaikan sistem elektronik yang digunakan;

f. Iktikad baik untuk segera memberitahukan secara tertulis kepada pemilik data pribadi atas setiap kegagalan perlindungan data pribadi;

g. Ketersediaan aturan internal pengelolaan perlindungan data pribadi;

h. Tanggung jawab atas data pribadi yang berada dalam penguasaan pengguna;

i. Kemudahan akses dan koreksi terhadap data pribadi oleh pemilik data pribadi; dan j. Keutuhan, akurasi, dan keabsahan serta kemutakhiran data pribadi.

\section{Tanggung Gugat Penyedia Aplikasi Atas Terjadinya Kegagalan Perlindungan Data Pribadi Dari Pengguna Aplikasi E- commerce}

Pada dasarnya pembedaan istilah tanggung jawab dengan tanggung gugat sangat dipengaruhi perbedaan istilah yaitu antara responsibility dengan liability dalam kepustakaan berbahasa Inggris. Tanggung jawab dipadankan dengan responsibility sedangkan tanggung gugat padanannya liability. Ternyata ada juga yang menyamakan pengertian tanggung gugat dengan akuntabilitas (accountability) yang mengandung pengertian kesediaan untuk menggugat tanggung jawab yang sudah diberikan kepada orang yang menerima dan bersedia melaksanakan tugas tertentu. Menurut Peter Mahmud Marzuki, pengertian "tanggung jawab dalam arti liability diartikan sebagai tanggung gugat yang merupakan terjemahan dari liability/aanspralijkheid, bentuk spesifik dari tanggung jawab" (Marzuki, 2016). Pengertian tanggung gugat merujuk kepada posisi seseorang atau badan hukum yang dipandang harus membayar suatu bentuk kompensasi atau ganti rugi setelah adanya peristiwa hukum atau tindakan hukum.

Pendapat Peter Mahmud Marzuki ini tidak jauh berbeda dengan pendapat J.H. Niewenhuis, bahwa tanggung gugat merupakan kewajiban untuk menanggung ganti kerugian sebagai akibat pelanggaran norma. Perbuatan melanggar norma tersebut dapat terjadi disebabkan perbuatan melawan hukum atau wanpretasi. Nieuwenhuis menguraikan bahwa tanggung gugat itu bertumpu pada 2 (dua) tiang yaitu pelanggaran hukum dan kesalahan (Santo, 2021).

Pada masa lampau data dan software komputer tidak termasuk dalam suatu hal yang dapat diterapkan dalam prinsip strict liability (pertanggungjawaban tanpa kesalahan), karena data dan software dikategorikan sebagai intangible asset (aset yang tak berwujud). Namun, ternyata hal tersebut justru telah mengakibatkan perkembangan industri menjadi negatif bagi 
kepentingan perlindungan pengguna dan pengguna internet (Makarim, 2010).

Tokopedia selaku penyelenggara platform market E-commerce dengan sistem elektronik yang menyimpan data pribadi para penggunanya yang diperuntukan untuk menyediakan beberapa produk dan layanan jual beli online yang dapat dijangkau oleh pengguna secara luas. Biasanya terdapat beberapa informasi yang terkait dengan akun pengguna aplikasi tersebut, penyedia aplikasi akan melakukan tindakan penutupan toko/moderasi jika akun tersebut tidak dibuka atau tidak ada aktivitas jual beli dan mengunggah konten produk selama 90 hari. Pernyataan mengenai perlindungan privasi serta ruang lingkup tanggung jawab hukum Tokopedia selaku penyedia dan penyelenggara platform jual beli online dengan sistem elektronik terdapat pada tokopedia terms of condition dimana terjadi adanya suatu perjanjian kontraktual antara pengguna aplikasi baik pengguna maupun pelaku usaha dengan tokopedia selaku penyelenggara aplikasi Marketplace. Apabila terjadi permasalahan hukum antara pengguna dengan tokopedi, maka didasarkan pada perjanjian yang termaktub dalam term of use yang dicantumkan pihak tokopedia selaku penyelenggara Ecommerce, sesuai dengan Tokopedia term of condition yang telah disetujui oleh pengguna dan Tokopedia selaku penyelenggara dan penyedia aplikasi E-commerce maka pengguna setuju untuk beberapa hal sebagai berikut :

1. Pengguna bertanggung jawab secara pribadi untuk menjaga kerahasiaan akun dan password untuk semua aktivitas yang terjadi dalam akun Pengguna.

2. Tokopedia tidak akan meminta username, password maupun kode SMS verifikasi atau kode OTP milik akun Pengguna untuk alasan apapun, oleh karena itu Tokopedia menghimbau Pengguna agar tidak memberikan data tersebut maupun data penting lainnya kepada pihak yang mengatasnamakan Tokopedia atau pihak lain yang tidak dapat dijamin keamanannya.

3. Pengguna setuju untuk memastikan bahwa Pengguna keluar dari akun di akhir setiap sesi dan memberitahu Tokopedia jika ada penggunaan tanpa izin atas sandi atau akun Pengguna.
4. Pengguna dengan ini menyatakan bahwa Tokopedia tidak bertanggung jawab atas kerugian ataupun kendala yang timbul atas penyalahgunaan akun Pengguna yang diakibatkan oleh kelalaian Pengguna, termasuk namun tidak terbatas pada menyetujui dan/atau memberikan akses masuk akun yang dikirimkan oleh Tokopedia melalui pesan notifikasi kepada pihak lain melalui perangkat Pengguna, meminjamkan akun kepada pihak lain, mengakses link atau tautan yang diberikan oleh pihak lain, memberikan atau memperlihatkan kode verifikasi (OTP), password atau email kepada pihak lain, maupun kelalaian Pengguna lainnya yang mengakibatkan kerugian ataupun kendala pada akun Pengguna.

Apabila terjadi kegagalan perlindungan data pribadi oleh penyelenggara apliaksi Ecommerce (tokopedia), maka kewajiban yang harus dilakukan penyelenggara sistem elektronik berdasarkan Pasal 15 ayat (2) PP PSTE adalah memberitahukan secara tertulis perihal tersebut kepada pemilik data pribadi. Apabila data pibadi yang tersebar luas bukan dalam konteks yang diperjanjikan dalam terms and condition, maka berdasarkan Pasal 26 ayat (2) UU ITE pemilik data pribadi daat mengajukan gugatan ganti rugi kepada penyelenggara sistem elektronik (Ecommerce) melalui pengadilan negeri.

Perihal mengenai gugatan ganti kerugian pada umumnya terjadi karena adanya ingkar janji atau wanprestasi dan karena adanya perbuatan melanggar hukum atau onrechtmatige daad. Gugatan ganti rugi atas dasar "wanprestasi artinya tidak memenuhi kewajiban yang telah ditetapkan dalam perikatan" (Muhammad, 2003). Gugatan atas dasar wanprestasi diawali dengan tidak dipenuhinya suatu kewajiban yang timbul dari suatu perjanjian. Ganti rugi yang didasarkan atas suatu perjanjian, di mana salah satu pihak tidak memenuhi kewajiban yang didasarkan atas perjanjian dapat dikatakan ingkar janji atau wanprestasi

Prestasi merupakan kewajiban, yang berarti kewajiban yang harus dipenuhi oleh para pihak yang membuat perjanjian sebagai pelaksanaan dari perjanjian tersebut. Kewajiban yang timbul dari suatu perjanjian menurut Pasal 1234 BW yang menentukan bahwa "tiap-tiap perikatan adalah untuk memberikan sesuatu, untuk berbuat sesuatu, 
atau untuk tidak berbuat sesuatu". Hal ini berarti bahwa wujud prestasi dalam suatu perjanjian adalah untuk memberikan atau menyerahkan sesuatu atau tidak berbuat sesuatu. Dalam hubungannya perlindungan data pribadi bentuk prestasinya yaitu melakukan perbuatan yang tidak sesuai yang telah diperjanjikan bersama.

Munculnya hak dan kewajiban antara perusahaan penyelenggara sistem elektronik dengan pengguna ialah saat pengguna menyetujui Terms of Use (Syarat Penggunaan) perusahaan penyelenggara sistem elektronik. Dengan begitu telah terjadi perikatan yang terjadi antar para pihak. Terms of Use tersebut merupakan suatu kontrak elektronik yang di berikan oleh perusahaan penyelengara sistem eleketronik kepada pengguna untuk memenuhi atau mengikuti peraturan yang telah di buat oleh perusahaan. Dalam hal ini, pengguna mempercayakan data pribadi yang mereka miliki untuk di proses kepada perusahaan penyelenggara sistem elektronik.

Apabila atas perjanjian yang disepakati dan menimbulkan kerugian maka dapat diajukan gugatan wanprestasi, karena ada hubungan kontraktual antara pihak yang menimbulkan kerugian dan pihak yang menderita kerugian. Apabila tidak ada hubungan kontraktual antara pihak yang menimbulkan kerugian dan pihak yang menerima kerugian, maka dapat diajukan gugatan perbuatan melawan hukum.

Gugatan ganti rugi didasarkan atas adanya perbuatan melanggar hukum juga dapat menjadi salah satu alternatif karena juga dimungkinkan adanya hak privasi yang dilanggar akibat adanya kegagalan dalam perlindungan data pribadi. Gugatan ganti rugi didasarkan atas $\mathrm{PMH}$ harus memenuhi unsur Pasal 1365 BW yaitu "tiap perbuatan melawan hukum yang membawa kerugian kepada seorang lain, mewajibkan orang yang karena salahnya menerbitkan kerugian untuk mengganti kerugian tersebut." Adapun unsur - unsur yang harus dipenuhi untuk dapat dikabulkannya gugatan $\mathrm{PMH}$ terdapat 4 (empat) unsur yaitu (1) adanya perbuatan, (2) adanya kesalahan, (3) adanya kerugian, dan (4) adanya hubungan kausalitas antara perbuatan dan kerugian.

Dalam Pasal 1365 BW tersebut dijelaskan bahwa setiap orang tidak hanya bertanggung jawab terhadap kerugian yang disebabkan karena perbuatannya sendiri, tetapi juga terhadap kerugian yang ditimbulkan karena perbuatan orang-orang yang ditanggungnya, atau karena barangbarang yang berada di bawah pengawasannya. inti kata dari perbuatan tersebut adalah bertentangan dengan kewajiban hukum si pelaku, atau melanggar hak subjektif orang lain, atau melanggar kaidah tata susila (goede zeden), atau bertentangan dengan asas "Kepatutan", ketelitian serta sikap hati hati dalam pergaulan hidup masyarakat (Tanaya, 2013). Oleh karena itu, walaupun tokopedia merupakan entitas badan hukum tetap dapat dimintai pertanggungjawaban atas kegagalan perlindungan data pribadi yang diakibatkan oleh pekerjanya atau sistem elektronik yang di kelolanya.

Ditinjau dari UU ITE, PP PSTE, dan PERMENKOMINFO 20/2016, apabila terjadi penyalahgunaan data yang dapat menyebabkan kebocoran data karena beberapa sebab dan akibat yang dilakukan oleh Tokopedia memenuhi unsur diatas karena tokopedia berkomitmen untuk menjaga kerahasiaan data pribadi pengguna yang berada di bawah kendali Tokopedia dan menjamin tidak ada pengungkapan, penjualan, pengalihan, distribusi dan/atau peminjaman data pribadi pengguna kepada pihak ketiga lain, Namun yang terjadi saat ini data tersebut bocor karena pihak ketiga dan diperjual belikan di suatu situs website darknet tanpa adanya persetujuan dari Pengguna memberikan mengizinkan pihak ketiga untuk memberikan akses tersebut. Apabila timbul kerugian yang merupakan sebab akibat dari perbuatan tersebut, maka dari perbuatan tersebut tokopedia harus tanggung jawab atas terjadi kebocoran data pribadi pengguna aplikasi tersebut karena telah dianggap lalai terhadap keamanan dari data pribadi para pengguna nya.

Dapat disimpulkan bahwa penyelenggara sistem elektronik dalam hal ini adalah tokopedia yang telah gagal dalam melakukan perlindungan data pribadi dapat mintai tanggung gugat dengan terlebih dahulu menyelesaikannya secara musyawarah atau penyelesaian alternatif lainnya yang di mediasi oleh tim penyelesaian sengketa dari Kementerian Komunikasi Dan Informasi Republik Indonesia dengan dasar adanya pengaduan dari pemilik data pribadi atau 
penyelenggara sistem elektronik (vide Pasal 29 - 32 PERMENKOMINFO 20/2016). Selain itu, penyelenggara sistem elektronik dapat dikenai sanksi administartif berdasarkan Pasal 100 PP PSTE dan rekomendasi tim penyelesaian sengketa kegagalan perlindungan data pribadi. Bila penyelesaian sengketa tidak mencapai perdamaian dapat diajukan gugatan perdata baik wanprestasi maupun perbuatan melanggar hukum ke pengadilan negeri.

\section{KESIMPULAN}

1. Perlindungan hukum pengguna aplikasi $E$ commerce atas adanya kegagalan perlindungan data pribadi oleh $E$ commerce ditinjau menurut perlindungan hukum intern dan ekstern. Perlindungan hukum intern didasarkan pada term of use yang dicantumkan penyelenggara sistem elektronik sebelum pengguna aplikasi memasukkan data pribadinya. Dalam term of use tersebut penyelenggara sistem elektronik hanya dapat berupaya untuk menjamin perlindungan data pribadi pengguna aplikasi, tetapi manakala terjadi kebocoran penyelenggara sistem elektronik (E-commerce) tidak memberikan ruang untuk adanya upaya penyelesaian sengketa yang merupakan inisiasi dari pihak penyelenggara sistem elektronik (E-commerce). Selain itu, term of use tersebut merupakan klausula baku yang harus diterima oleh setiap pengguna aplikasi yang ingin menggunakan platform E-commerce tersebut. Perlindungan hukum ekstern diatur dalam beberapa ketentuan peraturan perundang undangan di Indonesia. Regulasi terkait perlindungan data pribadi hingga saat ini menjadi bagian dari regulasi dalam bidang informasi dan transaksi elektronik seperti UU ITE beserta perubahannya, PP 71/2019 Tentang PSTE, PP PMSE, dan PERMENKOMINFO 20/2016. Perlindungan hukum bagi pengguna aplikasi E-commerce manakala terjadi kegagalan perlindungan data pribadi diatur dalam ketentuan Pasal 26 ayat (2) UU ITE beserta perubahannya dan Pasal 14 ayat (5) jo Pasal 100 ayat (1) - (5) PP 71/2019 Tentang PSTE, Pasal 29 -32 PERMENKOMINFO 20/2016. Dari ketiga ketentuan tersebut dapat disimpulkan bahwa ketika terjadi kegagalan dalam perlindungan data pribadi, maka penyelenggara sistem elektronik (Ecommerce) diwajibkan untuk memberitahukan kepada pemilik data pribadi. Regulasi PP PSTE mengatur sanksi administratif apabila tidak memberithukan adanya kegagalan perlindungan data pribadi kepada pemilik data pribadi tersebut. Selain itu, sarana penyelesaian sengketa juga telah di atur dalam Pasal 29 - 32. PERMENKOMINFO 20/2016.

2. Penyelenggara sistem elektronik dalam hal ini adalah tokopedia yang telah gagal dalam melakukan perlindungan data pribadi dapat mintai tanggung gugat dengan terlebih dahulu menyelesaikannya secara musyawarah atau penyelesaian alternatif lainnya yang di mediasi oleh tim penyelesaian sengketa dari Kementerian Komunikasi Dan Informasi Republik Indonesia dengan dasar adanya pengaduan dari pemilik data pribadi atau penyelenggara sistem elektronik (vide Pasal 29 - 32 PERMENKOMINFO 20/2016). Selain itu, penyelenggara sistem elektronik dapat dikenai sanksi administartif berdasarkan Pasal 100 PP PSTE dan rekomendasi tim penyelesaian sengketa kegagalan perlindungan data pribadi. Bila penyelesaian sengketa tidak mencapai perdamaian dapat diajukan gugatan perdata baik wanprestasi maupun perbuatan melanggar hukum ke pengadilan negeri.

\section{DAFTAR PUSTAKA}

\section{Buku}

Isnaeni. Moch. Seberkas Diaroma Hukum Kontrak. Surabaya. PT Revka Petra Media. 2017.

Isnaeni, Moch. Pengantar Hukum Jaminan Kebendaan, Surabaya, Revka Petra Media, 2016.

Makarim. Edmon. Tanggung Jawab Hukum Penyelenggara Sistem Elektronik. Raja Grafindo Persada. Jakarta. 2010.

Marzuki, Peter Mahmud, Penelitian Hukum. Jakarta. Kencana Prenada Media Group. 2016. 
Muhammad, Abdulkadir, Hukum dan Penelitian Hukum, Bandung, Citra Aditya Bakti, 2004.

Hukum Perikatan. Bandung. Citra Aditya Bakti. 2003.

Sidabalok, Janus, Hukum Perlindungan Pengguna di Indonesia, Bandung, Citra Aditya Bakti, 2014.

Soekanto, Soerjono dan Sri Mamudji, Penelitian Hukum Normatif Suatu Tinjauan Singkat, Jakarta, Raja Grafindo Persada, 2009.

\section{Artikel Jurnal IImiah}

Barkatullah. Abdul Halim. Perlindungan Hukum bagi Konsumen dalam Transaksi E-commerce Lintas Negara di Indonesia. Disertasi. Yogyakarta. 2006

Velliana Tanaya, Rekonstruksi Asas Perbuatan Melawan Hukum dalam Sengketa Konsumen, Jurnal IImu Syariah dan Hukum Asy-Syir'ah, Volume 47, Nomor 1 Tahun 2013, h. 30.

\section{Sumber Nisbah Online}

Kebocoran data Tokopedia "Pakar orang RI tak tahu bahaya dari kebocoran data Tokopedia" Dikutip dari https://www.cnnindonesia.com/teknologi/ 20200505155313-185-500333/pakarorang-ri-tak-tahu-bahaya-dari-kebocorandata-tokopedia, <diunduh tanggal 29 september 2020>

Paulus Aluk Fajar Dwi Santo, "Konsepsi Tanggung Gugat", dikutip dari http://business-

law.binus.ac.id/2016/05.31/konsepsitanggung-gugat <diunduh tanggal 12 Januari 2021>

Tokopedia, "kebijakan privasi", dikutip dari https://www.tokopedia.com/privacy <diunduh tanggal 05/04/2021>
Tokopedia, "kebijakan privasi", dikutip dari https://www.tokopedia.com/privacy $<$ diunduh tanggal 07/04/2021>

\section{Peraturan Perundangan-Undangan}

Burgerlijk Wetboek.

Undang-Undang Nomor 11 Tahun 2008 Tentang Informasi dan Transaksi Elektronik, Lembaran Negara Republik Indonesia Tahun 2008 Nomor 58, Tambahan Lembaran Negara Republik Indonesia Nomor 4843.

Undang - Undang Nomor 19 Tahun 2016 Tentang Perubahan 11 Tahun 2008 Tentang Informasi dan Transaksi Elektronik, Lembaran Negara Republik Indonesia Tahun 2016 Nomor 251, Tambahan Lembaran Negara Republik Indonesia Nomor 5952.

Peraturan Pemerintah Nomor 71 Tahun 2019 Tentang Penyelenggaraan Sistem Dan Transaksi Elektronik, Lembaran Negara Republik Indonesia Tahun 2019 Nomor 185, Tambahan Lembaran Negara Republik Indonesia Nomor 6400.

Peraturan Pemerintah Republik Indonesia Nomor 80 Tahun 2019 Tentang Perdagangan Melalui Sistem Elektronik, Lembaran Negara Republik Indonesia Tahun 2019 Nomor 222, Tambahan Lembaran Negara Republik Indonesia Nomor 6420.

Peraturan Menteri Komunikasi dan Informatika Nomor 20 Tahun 2016 Tentang Perlindungan Data Pribadi Dalam Sistem Elektronik, Berita Negara Republik Indonesia Tahun 2016 nomor 1829 